\title{
Production of an Activated Carbon from a Banana Stem and its application as electrode materials for Supercapacitors
}

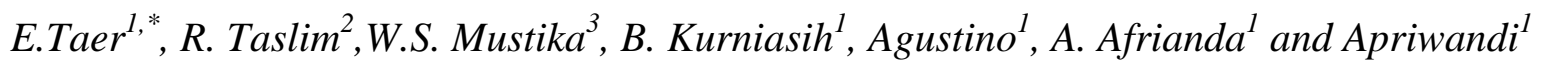 \\ ${ }^{1}$ Department of Physics, University of Riau, 28293 SimpangBaru, Riau, Indonesia \\ ${ }^{2}$ Departement of Industrial Engineering, Islamic State University of Sultan SyarifKasim, 28293 \\ SimpangBaru, Riau, Indonesia. \\ ${ }^{3}$ Department of Physics, Institute of Technology of Bandung, Bandung, West Java, Indonesia \\ *E-mail: erman_taer@yahoo.com
}

doi: $10.20964 / 2018.09 .55$

Received: 5 May 2018/ Accepted: 2 July 2018 / Published: 5 August 2018

\begin{abstract}
The production of activated carbon electrodes from a banana stem for supercapacitor cell applications has been successfully performed. The increase in pore properties was conducted using a $\mathrm{KOH}$ chemical activation agent at low concentrations of $0.0,0.3,0.5$ and $0.7 \mathrm{M}$, whereas physical activation was performed using $\mathrm{CO}_{2}$ gas at a temperature of $850{ }^{\circ} \mathrm{C}$ for $2 \mathrm{~h}$. The activated carbon electrode was fabricated without the addition of adhesive materials. The density, degree of crystallinity, surface morphology, elemental content and surface area of the electrodes were analyzed. The study of electrochemical properties focused on the analysis of the specific capacitance of the supercapacitor cell using cyclic voltammetry. The physical properties of the activated carbon electrodes were correlated to generate the optimum conditions for the specific capacitance of the supercapacitor cells. The optimum specific capacitance obtained at a concentration of $0.5 \mathrm{M} \mathrm{KOH}$ reached $170 \mathrm{~F} / \mathrm{g}$ with a specific surface area of $835.939 \mathrm{~m}^{2} / \mathrm{g}$.
\end{abstract}

Keywords:banana stem; activated carbon; specific capacitance; supercapacitor

\section{$\underline{\text { FULL TEXT }}$}

(C) 2018 The Authors. Published by ESG (www.electrochemsci.org). This article is an open access article distributed under the terms and conditions of the Creative Commons Attribution license (http://creativecommons.org/licenses/by/4.0/). 